A $\mathrm{C} \underset{\text { publications }}{\mathrm{C}} \mathrm{Rec. \text {Nat.Prod.15:4(2021)261-266 }}$

records of natural

products

\title{
A New Phenylpropanoid from the Roots of Solanum melongena L. and Evaluation of Anti-inflammatory Activity
}

\author{
Yan Liu $\oplus^{1}$, Xin Yin $\oplus^{2}$, Yanping Sun $\oplus^{1}$ Yuan Liu $\oplus^{1}$, Dongxv Lu $\oplus^{1}$, \\ Yuanyuan Zhou ${ }^{1}$, Mohammed Algradi Adnan ${ }^{1}$, Juan Pan@1, \\ Wei Guan $\oplus^{1}$, Bingyou Yang $\oplus^{1^{*}}$ and Haixue Kuang $\odot{ }^{1 *}$
}

\author{
1 Key Laboratory of Chinese Materia Medica, Ministry of Education of Heilongjiang University of \\ Chinese Medicine, Harbin 150040, P.R. China \\ 2 Guizhou University of Traditional Chinese Medicine, Guiyang 550000, People's Republic of China
}

(Received October 08, 2020; Revised November 12, 2020; Accepted November 13, 2020)

\begin{abstract}
Fifteen phenylpropanoids were isolated from the ethanol extract of Solanum melongena L. roots, including a new compound, melongenapanoid A (1), and fourteen known compounds (2-15) were isolated from the species. Their chemical structures were elucidated by interpreting the 1D and 2D NMR and HR-MS data as well as in comparison with the literature. The anti-inflammatory activities of isolates were evaluated by measuring their inhibitory activities on nitric oxide (NO) production induced by lipopolysaccharide (LPS) in RAW 264.7 cell line. Compounds 2, 4 and $\mathbf{5}$ showed potential inhibition of NO production with $\mathrm{IC}_{50}$ values of 28.7, 24.4 and 32.6 $\mu \mathrm{M}$, respectively.
\end{abstract}

Keywords: Solanum melongena L.; natural products; phenylpropanoids; anti-inflammatory activity. (C) 2020 ACG Publications. All rights reserved.

\section{Introduction}

Solanum melongena L. (Solanaceae), is widely distributed across the world, and there are 40 species and 14 varieties of the genus Solanum were cultivated in the different parts of China $[1,4]$. As a traditional Chinese medicine, the roots of Solanum melongena L., are widely used for the treatment of chilblains, wind-damp-heat syndrome, and toothache. The pharmacological studies showed that the Solanum melongena L. have antioxidant [2], anti-inflammatory [3], antitumor [4]. Previous phytochemical investigations on genus Solanum have identified more than 100 compounds, which include flavonoids [5], steroidal glycosides [6,7], steroids [8,9], phenylpropanoid amides [1], alkaloids [4]. Among them, there are more than 30 kinds of alkaloids and they are also the main active components, and the extract has anti-inflammatory activity $[4,10,11]$, but no one has elucidated the active substance. In order to discover the phenylpropanoids with anti-inflammatory activity, the $70 \%$

\footnotetext{
*Corresponding author: E-mail: ybywater@163.com (B-Y. Yang), hxkuang@yahoo.com (H-X. Kuang).
} 
ethyl alcohol extracts of Solanum melongena L. roots were subjected to phytochemistry identification, leading to the isolation of one new phenylpropanoid, melongenapanoid A (1), together with fourteen knowns (2-15) for the first time isolated from this plant. While, the determination of the antiinflammatory activity of isolates by measuring their inhibitory activities on NO production by LPSinduced RAW 264.7 cell line was carried out. The isolation, structural elucidation, and antiinflammatory activity procedures details were reported in the following section.

\section{Materials and Methods}

\subsection{Materials and Instruments}

NMR spectra were obtained on Bruker DPX 400 instrument (Bruker, Karlsruhe, Germany) and the optical rotations were determined with a JASCO P-2000 instrument (Jasco, Tokyo, Japan) while, the HR-ESI-MS data was recoreded on Waters Xevo-TOF-MS (Waters, Milford, America). Semipreparative HPLC was conducted with a Waters XBridgeTM Prep C18 column $(250 \times 10 \mathrm{~mm}, 5 \mu \mathrm{m})$ (Waters, Milford, America), and the HPLC system was equipped with a Shimadzu CBM-20A, RID detector, and LC-6AD pump (Shimadzu, Tokyo, Japan). Column chromatography was performed using silica gel of 100-120 mesh and 200-300 mesh (Qingdao Marine Chemical Co., Qingdao, China), ODS (YMC Company Ltd., Japan), and Sephadex LH-20 (Merck, Germany). All the solvents were of analytical grade (Tianjinfuyu Co., Tianjin, China).

The roots of Solanum melongena L. were collected in September 2016 from Anguo City, Hebei Province, People's Republic of China. They were identified by Prof. Rui-Feng Fan of the Heilongiiang University of Chinese Medicine. The voucher specimen (No. 20160918) was deposited in Heilongiiang University of Chinese Medicine, Harbin, China.

\subsection{Isolation of Compounds}

The dried roots of S. melongena $(20 \mathrm{~kg})$ were extracted with $70 \%$ ethanol under reflux for three times $(2 \mathrm{~h}$, each), and the solvent was recovered to afford the extract $(1503 \mathrm{~g})$. The extract was separated through MCI chromatographic column and successively eluted by $30 \%, 60 \%$, and $80 \% \mathrm{CH}_{3} \mathrm{OH}$. The different elutions were dried under vacuum to afford $30 \% \mathrm{CH} 3 \mathrm{OH}$ fraction $(\mathrm{A}, 597 \mathrm{~g}), 60 \% \mathrm{CH}_{3} \mathrm{OH}$ fraction $(\mathrm{B}, 403 \mathrm{~g})$, and $80 \% \mathrm{CH}_{3} \mathrm{OH}$ fraction $(\mathrm{C}, 171 \mathrm{~g})$, respectively.

Fraction B (200 g) was subjected to silica gel column chromatography $\left(\mathrm{CH}_{2} \mathrm{Cl}_{2}-\mathrm{CH}_{3} \mathrm{OH}, 1: 0-\right.$ $0: 1, \mathrm{v} / \mathrm{v}$ ) to afford nine fractions B1-B9. Fraction B2 was separated by ODS column chromatography with $\mathrm{MeOH}-\mathrm{H}_{2} \mathrm{O}$ (2:8 to 1:0) to afford sub-fractions B2A-B2K. Sub-fraction B2F was applied to semipreparative HPLC to yield compounds $\mathbf{1}(1.5 \mathrm{mg}), \mathbf{5}(14.3 \mathrm{mg}), \mathbf{6}(3.7 \mathrm{mg}), \mathbf{1 3}(4.2 \mathrm{mg})$, and $\mathbf{1 5}(1.4$ $\mathrm{mg}$ ), respectively. Fraction B3 was purified through semi-preparative HPLC to afford compounds 14 $(8.4 \mathrm{mg})$. Fraction B4 was separated by semi-preparative HPLC to yield compounds 2 (3.7 $\mathrm{mg}), \mathbf{3}(5.3$ $\mathrm{mg}), \mathbf{1 0}(3.0 \mathrm{mg})$, and $\mathbf{1 1}(8.8 \mathrm{mg})$.

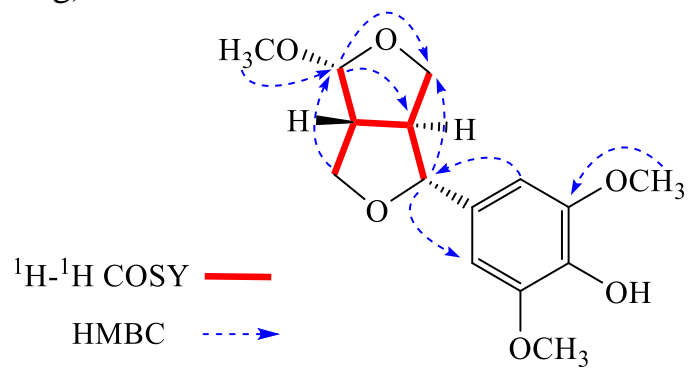

1

Figure 1. ${ }^{1} \mathrm{H}-{ }^{1} \mathrm{H}$ COSY correlations and the selected $\mathrm{HMBC}$ correlations of compound $\mathbf{1}$

Fraction $\mathrm{C}(150 \mathrm{~g})$ was subjected to silica gel column chromatography $\left(\mathrm{CH}_{2} \mathrm{Cl}_{2}-\mathrm{CH}_{3} \mathrm{OH}, 1\right.$ :00:1, v/v) to afford seven fractions C1-C7. Sub-fraction C2 was performed on Sephadex LH-20 eluted with $\mathrm{MeOH}$ to give ten sub-fractions $\mathrm{C} 2 \mathrm{~A}-\mathrm{C} 2 \mathrm{~J}$. Fractions $\mathrm{C} 2 \mathrm{D}$ was purified by semi-preparative HPLC to yield compounds 4 (2.9 mg), 7 (17.9 mg), $8(4.0 \mathrm{mg})$, and $\mathbf{9}(1.9 \mathrm{mg})$. Sub-fraction C2F was performed 
on Sephadex LH-20 (MeOH) and purified by semi-preparative HPLC to obtain compounds 7 (2.6 mg) and $12(6.9 \mathrm{mg})$.

\subsection{Spectroscopic Data}

Melongenapanoid A (1): White amorphous powder. $[\alpha]_{D}^{21}=+7.5,(c=1.2, \mathrm{MeOH}) ; \operatorname{IR}(\mathrm{KBr}) v$ 2935, 1754, 1425, 1308, 1240, $1017 \mathrm{~cm}^{-1} ;{ }^{1} \mathrm{H}-\mathrm{NMR}$ (MeOH, $400 \mathrm{MHz}$ ) and ${ }^{13} \mathrm{C}-\mathrm{NMR}(\mathrm{MeOH}, 100$ $\mathrm{MHz}$ ), see Table 1; The pseudomolecular-ion peaks in the HR-ESI-MS $m / z 319.1152[\mathrm{M}+\mathrm{Na}]^{+}$(calcd. for $\mathrm{C}_{15} \mathrm{H}_{20} \mathrm{O}_{6} \mathrm{Na}, 319.1152$ ).

\section{Results and Discussion}

\subsection{Structure Elucidation}

Compound 1 was obtained as a white amorphous powder. The pseudomolecular-ion peaks in the HR-ESI-MS $m / z 319.1152[\mathrm{M}+\mathrm{Na}]^{+}$(calcd. for $\mathrm{C}_{15} \mathrm{H}_{20} \mathrm{O}_{6} \mathrm{Na}, 319.1152$ ), and the fragment ion peak at 265.1080 showed that one methoxy group was removed (Figure S1). The ${ }^{1} \mathrm{H}-\mathrm{NMR}$ spectrum of $\mathbf{1}$ (Table 1) represented a group of 1,3,4,5-disubstituted benzene rings proton signals at $\delta_{\mathrm{H}} 6.61(2 \mathrm{H}, \mathrm{s}, \mathrm{H}-2,6)$, two pairs of oxide methylenes proton signals $\left[\delta_{\mathrm{H}} 4.14(1 \mathrm{H}, \mathrm{dd}, J=12.6,4.2 \mathrm{~Hz}, \mathrm{H}-1\right.$ 'a) and $4.02(1 \mathrm{H}$, dd, $J=12.6,8.4 \mathrm{~Hz}, \mathrm{H}-1 \mathrm{'b}), 4.00(1 \mathrm{H}, \mathrm{dd}, J=11.4,3.0 \mathrm{~Hz}, \mathrm{H}-9 \mathrm{a})$ and $3.83(1 \mathrm{H}$, overlap, $\mathrm{H}-9 \mathrm{~b})]$, as well as four methylene signals $\left[\delta_{\mathrm{H}} 4.59(1 \mathrm{H}, \mathrm{d}, J=7.8 \mathrm{~Hz}, \mathrm{H}-7), 2.97(1 \mathrm{H}, \mathrm{m}, \mathrm{H}-8), 3.17\left(1 \mathrm{H}, \mathrm{m}, \mathrm{H}-2^{\prime}\right)\right.$ and 4.93 $\left.\left(1 \mathrm{H}, \mathrm{d}, J=5.4 \mathrm{~Hz}, \mathrm{H}-3^{\prime}\right)\right]$. In addition, three methoxy groups existed at $\delta_{\mathrm{H}} 3.83\left(6 \mathrm{H}, \mathrm{s}, 3,5-\mathrm{OCH}_{3}\right)$ and $3.42\left(3 \mathrm{H}, \mathrm{s}, 3^{1}-\mathrm{OCH}_{3}\right)$. The combination of ${ }^{13} \mathrm{C}$ NMR and $\mathrm{HSQC}$ spectra exhibited 15 carbon signals including a group of ,3,4,5-disubstituted benzene rings [ $\left(\delta_{\mathrm{C}} 133.1, \mathrm{C}-1\right),\left(\delta_{\mathrm{C}} 104.6, \mathrm{C}-2\right.$ and 6$),\left(\delta_{\mathrm{C}} 149.3\right.$, $\mathrm{C}-3$ and 5$\left.),\left(\delta_{\mathrm{C}} 136.3, \mathrm{C}-4\right)\right]$, four methylene carbons [ $\left(\delta_{\mathrm{C}} 87.3, \mathrm{C}-7\right),\left(\delta_{\mathrm{C}} 54.1, \mathrm{C}-8\right),\left(\delta_{\mathrm{C}} 51.9, \mathrm{C}-2\right),\left(\delta_{\mathrm{C}}\right.$ $\left.\left.106.1, \mathrm{C}-3^{\prime}\right)\right]$ and three methoxy groups, together with a methylene signals. Then, the whole structure of compound 1 was connected on basis of the ${ }^{1} \mathrm{H}-{ }^{1} \mathrm{H}$ COSY and HMBC correlations (Figure S5-9). Meanwhile, the attachments of the methoxy groups to C-3, C-5 and C-3' were confirmed by the HMBC cross peaks of $\delta_{\mathrm{H}} 3.83\left(3,5-\mathrm{OCH}_{3}\right)$ to $\mathrm{C}-3$ and $\mathrm{C}-5, \delta_{\mathrm{H}} 3.842\left(3^{\prime}-\mathrm{OCH}_{3}\right)$ to $\mathrm{C}-3$ '. By comparing the reference [12], H-7 was confirmed to be $\beta$ configuration. The correlations of $\delta_{\mathrm{H}} 3.17$ and 4.59 showed that $\mathrm{H}-2^{\prime}$ was $\beta$ configuration, and the correlations of $\delta_{\mathrm{H}} 4.02$ and 2.97, 4.59 and 4.14 proved that $\mathrm{H}-8$ was $\alpha$ configuration, and the correlations of $\delta_{\mathrm{H}} 4.93$ and 3.83 showed that $\mathrm{H}-3$ ' was $\beta$ configuration by NOE spectrum (Figure S10). Therefore, the planar structure of melongenapanoid A (1) was established as shown in Figure 1.

Table 1. ${ }^{1} \mathrm{H}$ and ${ }^{13} \mathrm{C}$ NMR data of compound 1 (400 and $100 \mathrm{MHz}$, in $\mathrm{CD}_{3} \mathrm{OD}$ )

\begin{tabular}{|c|c|c|c|c|c|}
\hline No & $\delta_{\mathrm{C}}$ & $\delta_{\mathrm{H}}$ & No & $\boldsymbol{\delta}_{\mathbf{C}}$ & $\delta_{H}$ \\
\hline 1 & 133.1 & - & $1^{\prime}$ & 67.9 & $4.14(1 \mathrm{H}, \mathrm{dd}, 12.6,4.2)$ \\
\hline 2,6 & 104.6 & $6.61(2 \mathrm{H}, \mathrm{s})$ & & & $4.02(1 \mathrm{H}, \mathrm{dd}, 12.6,8.4)$ \\
\hline 3,5 & 149.3 & - & $2^{\prime}$ & 51.9 & $3.17(1 \mathrm{H}, \mathrm{m})$ \\
\hline 4 & 136.3 & - & $\mathbf{3}^{\prime}$ & 106.1 & $4.93(1 \mathrm{H}, \mathrm{d}, 5.4)$ \\
\hline 7 & 87.3 & $4.59(1 \mathrm{H}, \mathrm{d}, 7.8)$ & $3-\mathrm{OCH}_{3}$ & 56.7 & $3.83(6 \mathrm{H}, \mathrm{s})$ \\
\hline 8 & 54.1 & $2.97(1 \mathrm{H}, \mathrm{m})$ & $5-\mathrm{OCH}_{3}$ & 56.7 & $3.83(6 \mathrm{H}, \mathrm{s})$ \\
\hline \multirow[t]{2}{*}{9} & 69.6 & $4.00(1 \mathrm{H}, \mathrm{dd}, 11.4,3.0)$ & $3^{\prime}-\mathrm{OCH}_{3}$ & 55.9 & $3.42(3 \mathrm{H}, \mathrm{s})$ \\
\hline & & $3.83(1 \mathrm{H}, \mathrm{o})$ & & & \\
\hline
\end{tabular}

The fourteen known compounds were identified by comparison of their spectroscopic data with those reported in the literatures as (7R,7'R,7"S,7'"S,8S, 8'S,8"S,8"'S)-4",4'"-dihydroxy-3,3',3",3'",5,5'hexamethoxy-7,9',7',9-diepoxy-4,8',4',8"'-bisoxy-8,8'-dineolignan-7",7"',9",9"'-tetraol (2) [13], (7R,7'R, 7"R,7'"S, 8S,8'S,8"S, 8'"S)-4",4"'-dihydroxy-3,3',3",3'",5,5'-hexamethoxy-7, 9',7',9-diepoxy-4,8',4',8'"'-bisoxy-8,8'-dineolignan-7",7"',9",9"'-tetraol (3) [13], threo-buddlenol A (4) [14], lirioresinol A (5) [15], 
7'-hydroxyl-syringaresinol (6) [16], meliasendanin D (7) [17], threo-dihydroxydehy-drodiconiferylalcohol (8) [17], (7S,8S)-4-hydroxy-3,1',3'-trimethoxy-4',7-epoxy-8,5'-neolign-9-ol (9) [18], 1,2-bis (4hydro xy-3-methoxyphenyl)propane-1,3-diol (10) [19], threo-2,3-bis-(4-hydroxy-3- methoxyphenyl)-3raethoxypropanol (11) [3], C-veratroylglycol (12) [20], 2-methoxy-4-(3-methoxy-l-propenyl)-phenol (13) [21], 7-O-ethylguaiacylglycerol (14) [22], isoscopoletin (15) [23] (Table S1 and Figure S11).

The anti-inflammatory test of isolated compounds was evaluated by measuring their inhibitory activities on NO production by LPS-induced RAW 264.7 cell line [24]. In brief, RAW 264.7 cells $(1 \times 105$ cells in $100 \mu \mathrm{L})$ were cultivated in 96-well microplates for $24 \mathrm{~h}$, and LPS $(1.0 \mu \mathrm{g} / \mathrm{mL})$ was added, as well as the serum-free medium with various concentrations of compounds $1-15$. After $24 \mathrm{~h}$ treatment, the supernatant was transferred to another 96-well microplate, $0.15 \% \mathrm{~N}$-(1-naphtyl)ethylenediamine and $1.5 \%$ sulfanilamide in $7.5 \%$ phosphoric acid $(50 \mu \mathrm{L})$ were added. After incubation for $30 \mathrm{~min}$, the absorbances were measured at $570 \mathrm{~nm}$ using a microplate reader.

The results of inhibitory activities (Table 2) against NO production suggested that compounds 1, 2-8, 10-11 and 13 exhibited different levels of inhibitory activities on NO production, and other compounds were not active $\left(\mathrm{IC}_{50}\right.$ values $>80 \mu \mathrm{M}$ ). Especially, compounds $\mathbf{2 , 4}$ and 5 showed better activities than the positive control of Indomethacina with $\mathrm{IC}_{50}$ values of $28.7,24.4$ and $32.6 \mu \mathrm{M}$, respectively.

Table 2. Inhibitory effects of compounds 1-15 on NO production by LPS-induced RAW264.7 cells.

\begin{tabular}{cc|cc}
\hline Compound & $\mathbf{I C}_{\mathbf{5 0}}(\mathbf{m e a n} \pm \mathbf{S D}, \boldsymbol{\mu M})$ & Compound & $\mathbf{I C}_{\mathbf{5 0}}(\mathbf{m e a n} \pm \mathbf{S D}, \boldsymbol{\mu M})$ \\
\hline $\mathbf{1}$ & $56.4 \pm 3.4$ & $\mathbf{9}$ & $>80$ \\
$\mathbf{2}$ & $28.7 \pm 1.9$ & $\mathbf{1 0}$ & $46.7 \pm 2.6$ \\
$\mathbf{3}$ & $70.7 \pm 4.8$ & $\mathbf{1 1}$ & $50.5 \pm 3.3$ \\
$\mathbf{4}$ & $24.4 \pm 1.7$ & $\mathbf{1 2}$ & $>80$ \\
$\mathbf{5}$ & $32.6 \pm 2.7$ & $\mathbf{1 3}$ & $68.9 \pm 4.1$ \\
$\mathbf{6}$ & $41.7 \pm 3.0$ & $\mathbf{1 4}$ & $>80$ \\
$\mathbf{7}$ & $43.4 \pm 3.1$ & $\mathbf{1 5}$ & $>80$ \\
$\mathbf{8}$ & $66.8 \pm 4.4$ & Indomethacin $^{\mathrm{a}}$ & $39.6 \pm 2.2$ \\
\hline
\end{tabular}

${ }^{a}$ Positive control

There are many kinds of phenylpropanoids, including simple phenylpropanoids, flavonoids, lignans, etc. In the present study, fifteen phenylpropanoids were obtained from the roots of Solanum melongena $\mathrm{L}$., including five simple lignans $(\mathbf{1}, \mathbf{1 2 - 1 5})$ four bisepoxylignans $(\mathbf{2}, \mathbf{3}, \mathbf{5}$, and $\mathbf{6})$, four benzofuran lignans $(\mathbf{4}, \mathbf{7 - 9})$, and two other lignans $(\mathbf{1 0}, \mathbf{1 1})$. All the compounds enrich the chemical diversity of $S$. melongena and deepened the research on the phenylpropanoids of S. melongena.

Lirioresinol A (5), 7-O-ethylguaiacylglycerol (14), and isoscopoletin (15) are all found from the family Rubiaceae [20,22,25], and (7R,7'R,7"S,7"'S,8S, 8'S, 8"S, 8''S)-4",4"'-dihydroxy-3,3',3",3"',5,5'hexamethoxy-7,9',7',9-diepoxy-4,8',4',8'"-bisoxy-8,8'-dineolignan-7",7"',9",9'"-tetraol (2), (7R,7'R,7'R, 7'"S, 8S, 8'S, 8"S, 8''S)-4",4"'-dihydroxy-3,3',3",3"',5,5'-hexamethoxy-7,9',7',9-diepoxy-4,8',4',8"'-bisoxy$8,8^{\prime}$-dineolignan7",7"',9",9"'-tetraol (3), and C-veratroylglycol (12) are all found from the family Celastraceae $[10,26]$ previously. Therefore, the family Solanaceae is relevant to the family Celastraceae and Rubiaceae.

As a conclusion, we reported a new compound and from the species herein. Compounds 2, 4 and $\mathbf{5}$ showed inhibitory activity on NO production by LPS-induced RAW264.7 cells

\section{Acknowledgments}

This work was financially supported by the China Postdoctoral Science Foundation (2018M631978), University Nursing Program for Yong Scholars with Creative Talents in Heilongjiang Province (UNPYSCT-2017221), Heilongjiang University of Chinese medicine Founds (2018pt01, 2018bs03), and National Key Research and Development Project (2018YFC1707100). 


\section{Supporting Information}

Supporting information accompanies this paper on http://www.acgpubs.org/journal/records-ofnatural-products

\section{ORCID}

Yan Liu: 0000-0003-4910-775X

Xin Yin: 0000-0002-8074-686X

Yanping Sun: 0000-0003-0105-5137

Yuan Liu: 0000-0001-6994-8420

Dongxv Lu: 0000-0001-6475-888X

Yuanyuan Zhou: 0000-0003-0258-791X

Mohammed Algradi Adnan: 0000-0003-2885-4545

Juan Pan: 0000-0001-9294-7901

Wei Guan: 0000-0001-5866-4801

Bingyou Yang: 0000-0002-2310-2750

Haixue Kuang: 0000-0002-5760-007X

\section{References}

[1] J. Sun, H. X. Huo, J. Zhang, Z. Huang, J. Zheng, Q. Zhang, Y. F. Zhao, J. Li and P. F. Tu (2015). Phenylpropanoid amides from the roots of Solanum melongena L. (Solanaceae), Biochem. Syst. Ecol. 58, 265-269.

[2] B. Okmen, H. O. Sigva, S. Mutlu, S. Doganlar, A. Yemenicioglu and A. Frary (2009). Total antioxidant activity and total phenolic contents in different Turkish eggplant (Solanum melongena L.) cultivars, Int. J. Food Prop. 12, 616-624.

[3] J. Bai (2018). Pharmacological effects of eggplant root and its research progress, World Latest Med. Inform. 18, 27-27.

[4] D. Y. Zhao, Y. Liu, X. Yin, X. M. Li, J. Pan, W. Guan, B. Y. Yang and H. X. Kuang (2020). Two new alkaloids from the sepals of Solanum melongena L., Nat. Prod. Res. 1-9 doi: 10.1080/14786419.2020.1713126

[5] J. Sun, Y. F. Gu, X. Q. Su, M. M. Li, H. X. Huo, J. Zhang, K. W. Zeng, Q. Zhang, Y. F. Zhao, J. Li and P. F. Tu (2014). Anti-inflammatory lignan amides from the roots of Solanum melongena L., Fitoterapia 98, 110-116.

[6] J. Sun, H. X. Huo, J. Zhang, Z. Huang, J. Zheng, Q. Zhang, Y. F. Zhao, J. Li and P. F. Tu (2015). Phenylpropanoid amides from the roots of Solanum melongena L. (Solanaceae), Biochem. Syst. Ecol. 58, 265-269.

[7] Y. L. Lin, W. Y. Wang, Y. H. Kuo and C. F. Chen (2000). Nonsteroidal constituents from Solanum incanum L., J. Chin. Chem. Soc. 47, 247-251.

[8] M. Ono, K. Nishimura, K. Suzuki, T. Fukushima, K. Igoshi, H. Yoshimitsu T. Ikeda and T. Nohara (2006). Steroidal glycosides from the underground parts of Solanum sodomaeum, Cheminform 37 https://doi.org/10.1002/chin.200628178.

[9] M. Ono, Y. Uenosono, H. Umaoka, Y. Shiono, T. Ikeda, M. Okawa, J. Kinjo, H. Yoshimitsu and T. Nohara (2009). Five new steroidal glycosides from the stems of Solanum sodomaeum, Chem. Pharm. Bull. 57, 759-763.

[10] W. W. Alphonse, K. T. Paul and C. C. Sumesh (2003). A novel glycosidic steroidal alkaloid from Solanum aculeastrum, Bull. Chem. Soc. Ethiop. 17, 61-66.

[11] X. H. Zhu, J. Ando, M. Takagi, T. Ikeda and T. Nohara, (2010). Four novel withanolide-type steroids from the leaves of Solanum cilistum, Chem. Pharm. Bull. 49, 1440-1443.

[12] F. X. Cai, I. S. Lee, N. T. Dat, G. Shen, J. S. Kang, D. H. Kim and Y. H. Kim (2004). Inhibitory lignans against NFAT transcription factor from Acanthopanax koreanum, Arch. Pharm. Res. 27, 738-741.

[13] J.X. Zhu, J. Ren, J.J. Qin, X.R. Cheng, Q. Zeng, F. Zhang, S.K. Yan,H.Z. Jin and W.D. Zhang (2012). Phenylpropanoids and lignanoids from Euonymus acanthocarpus, Arch. Pharm. Res. 35, 1739-1747. 
[14] J. Y. Zhu, B. Cheng, Y. J. Zheng, Z. Dong, S. L. Lin, G. H. Tang, Q. Gu and S. Yin (2015). Enantiomeric neolignans and sesquineolignans from Jatropha integerrima and their absolute configurations, RSC Adv. 5, 12202-12208.

[15] M. M. Xu, Y. H. Duan, H. H. Xiao, Y. Dai, Z. Z. Wang, M. S. Wong, X. S. Yao and W. Xiao (2014). Lignans isolated from stems of Sambucus williamsii and their proliferation effects on UMR106 cells, Chin. J. Chin. Pat. Med. 39(14), 2684-2688.

[16] Y. Kamaya, F. Nakatsubo and T. Higuchi (1983). Degradation of trimeric lignin model compounds, arylglycerol- $\beta$ - syringaresinol ethers, by Fusarium solani M-13-1, Agr. Biol. Chem. 47(2), 299-308.

[17] L. Wang, F. Li, C. Y. Yang, A. A. Khan, X. Liu and M. K. Wang (2014). Neolignans, lignans and glycoside from the fruits of Melia toosendan, Fitoterapia 99, 92-98.

[18] L. Zhang, B. B. Li, H. Z. Li, X. Meng, X. Lin, Y. Y. Jiang, J. S. Ahn and L. Cui (2017). Four new neolignans isolated from Eleutherococcus senticosus and their protein tyrosine phosphatase 1B inhibitory activity (PTP1B), Fitoterapia 121, 58-63.

[19] H. Kawamoto, S. Horigoshi and S. Saka (2007). Pyrolysis reactions of various lignin model dimers, $J$. Wood. Sci. 53(2), 168-174.

[20] S. R. Li, H. Yang, C. Tan and Z. H. Wang (2015). Chemical constituents of ethyl acetate fraction from the stems of Saprosma merrillii Lo, Chin. Pharm. J. 50(12), 1017-1020.

[21] T. Naito, K. Niitsu, Y. Ikeya, M. Okada, H. Mitsuhashi (1992). A phthalide and 2-farnesyl-6-methyl benzoquinone from Ligusticum chuangxiong, Phytochemistry 31, 1787-1789.

[22] X. W. Yang, P. J. Zhao, Y. L. Ma, H. T. Xiao, Y. Q. Zuo, H. P. He, L. Li and X. J. Hao (2007). Mixed lignin-neolignans from Tarenna attenuata, J. Nat. Prod. 70, 521-525.

[23] M. Adfa, T. Yoshimura, K. Komura and M. Koketsu (2010). Antitermite activities of coumarin derivatives and scopoletin from Protium javanicum Burm, f. J. Chem. Ecol. 36, 720-726.

[24] Y. R. Zheng, W. Wei and X. W. Yang (2018). Chuanliguspirolide, a new butylphthalide derivative from Chuanxiong Rhizomaand its inhibition on NO production in LPS-activated RAW264.7 and BV2 cell lines, Chin.Tradit. Herbal Drugs 49, 1497-1503.

[25] X. Q. Shi, G. X. Ma, H. Zhang, R. Huang, L. Han, M. T. Zhang, Y. R. Zhang, X. D. Xu, S. C. Yu and S. J. Liu (2018). Study on the chemical components in the rattan of Rubia argyi L. China Pharmacist.

[26] Z. H. Yan, Z. Z. Han, X. Q. Hu, Q. X. Liu, W. D. Zhang, R. H. Liu and H. L. Li (2013). Chemical constituents of Euonymus alatus, Chem. Nat. Compound. 49, 340-342.

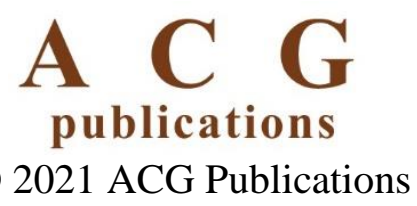

